\title{
The importance of physiotherapy in the sexuality of patients with rheumatic diseases
}

\author{
Beata Żuk ${ }^{1}$, Maria Maślińska² \\ ${ }^{1}$ Department of Biophysics and Human Physiology, Medical University of Warsaw, Poland \\ ${ }^{2}$ Early Arthritis Clinic, National Institute of Geriatrics, Rehabilitation and Rheumatology, Warsaw, Poland
}

\begin{abstract}
The sexuality of patients with rheumatic diseases is a significant interdisciplinary problem, requiring intensified action not only of rheumatologists, sexologists, and psychologists but also physiotherapists. The sexuality problems and motor disability in chronic diseases such as rheumatoid arthritis or ankylosing spondylitis, as well as other rheumatic diseases, are generally still taboo subjects, rarely discussed by physicians and physiotherapists. Lack of mobility, hormonal imbalance, fatigue, and accompanying decreased quality of life have an impact on sexual dysfunction. Meanwhile sex, as an integral part of human personality, is an essential element of human life.
\end{abstract}

Key words: rheumatic diseases, physiotherapy, sexuality.

\section{Introduction}

The development of sexology began in the last 30 years of the twentieth century, and then the term "sexuality" first appeared in dictionaries. It is understood that this sphere of emotions and behaviour accompanying humans from birth to death is an innate, inherent part of his/her life. Sexual dysfunctions affect up to $20 \%$ the quality of life of people with disabilities, compared to a healthy population, as shown by the Copenhagen Centre for Quality of Life [1]. According to Lew-Starowicz, satisfaction with sexual life translates into satisfaction not only from life in a relationship and family life, but also from satisfaction with general health [2]. Men attach more importance to sexual intercourse; their approach to this subject is more automated than women's. By meeting a partner's expectations the man confirms his masculinity and increases his self-esteem.

For women sex life is the source of many emotions and intimate relationship with a partner, as well as an affirmation of femininity. In biological terms, sexuality is a natural need not only associated with procreation. During sexual intercourse, the brain exerts analgesic and relaxing endorphin. The organism is better oxygenated and the muscles become relaxed [3]. As Areskoug-Josefs- son notes, physiotherapy can positively affect patients' sexual health by improving their physical activity [4].

\section{The specifics of selected rheumatic diseases}

Major systemic inflammatory connective tissue diseases of chronic nature include, among others: rheumatoid arthritis (RA) and ankylosing spondylitis (AS). These diseases are characterised by pain in the joints and muscles, as well as functional disorders of the movement system [5].

Rheumatoid arthritis is a systemic disease with inflammatory lesions located mainly in synovial membranes. In general, it is characterised by symmetrical inflammation of many joints with pain, oedema, and morning stiffness. It affects mainly wrists, small joints of hands, feet, and other peripheral joints. Inflammatory changes are accompanied by weakness of the body, fatigue, diminished mood (including depression), weight loss, and increased sweating. Along with the duration of the disease, damage of the movement system with typical deformities of the fingers of the hands, feet, and other joints progresses. Changes in the cervical spine often occur, especially at the level of C1/C2 associated with 
transverse ligament damage and atlanto-axial subluxation (AAS), as well as basilar invagination (BI), and subaxial instability (SAI) with the risk of spinal cord injuries [5-7]. Ankylosing spondylitis, similarly to RA, belongs to diseases of unknown aetiology and individual variation of disability progression. This seronegative spondyloarthropathy is associated with inflammation of sacroiliac joints and spine joints (axial involvement) as well as peripheral joints. AS may be accompanied by uveitis, gut inflammation, and skin and mucous membrane changes [8]. Clinically, it is characterised by lower back pain (mainly of sacroiliac joints, sometimes with radicular pain) and chest pain, which makes breathing difficult (due to costo-vertebral joint involvement).

In the posture of the body alignment or increase of physiological curvature of the spine, often with forced head alignment, neck pain radiating to the occipital, temples, and forehead is observed in the sagittal plane. As the disease develops, the limitation of the spine mobility with narrowing of the field of vision is visible (the desire to look at one side forces the rotation of the whole body), as well as reduction of chest enlargement, and characteristic diaphragm breathing. The silhouette of the patient is tilted forward, and the secondary contractures in the joints make it difficult or impossible to hold an upright posture [7].

The rheumatic diseases listed above have a significant impact on the patients' vital activity, significantly reducing their quality of life, and decreasing their ability to work. In addition, chronic pain of varying intensity, changes in joint appearance, limitation of mobility, and limitation of self-efficacy are sources of many psychological problems (depression, anxiety) [9].

\section{The impact of reumatic diseases on the sexuality of patients}

It is assumed that the number of patients with rheumatic diseases in relation to the whole population is high. In Poland, as many as $1 \%$ of all adults aged between 30 and 55 years are affected by RA and more women than men suffer from the disease (the ratio of female patients to male is about $4: 1$ ). It should be noted, however, that first clinical symptoms may manifest in adolescence, i.e. around 16 years of age. In the case of AS, the prevalence is rarer (0.2-1.1\% of the Caucasian population) and more male-specific, with the symptoms between the age of 15-30 years. As noted by Kucharz, van Berlo, Kobelt, and other researchers, rheumatic diseases affect people whose lifetimes are related to sexual needs, reproduction, and their problems are mostly individual [10-12]. These diseases do not directly affect the sexuality of patients, but their clinical symptoms significantly limit sexual health, which according to the World Health Organisation is closely related to the physical, emotional, psychological, and social aspects of sexual wellbeing [13]. Available studies indicate that sexual problems concern on average 30 to $76 \%$ of RA patients, which results in loss of sexual interest and satisfaction from the quality of life [14-17]. Kobelt et al. [12] found that age, sex, well-being, physical fitness, and mood were significant predictors of sexual activity in RA. Sexual dysfunction also correlated with pain, depressive mood, and degree of motor activity, and did not correlate with the BASDAI (Bath Ankylosing Questionnaire) - the main method of assessing the disease activity [18].

Another important aspect of this problem is the acceptance of one's own body, especially by women. Changes in facial features, joint deformations, sometimes differences in length of lower limbs or changes in body posture and mobility deficits diverge from the attractiveness model imposed by the environment [4]. However, as reported by Hill et al. [19], fatigue and pain, limited mobility of the joints and oedema, reduced libido, and vaginal dryness are the most unfavourable factors affecting partner relationships. The problem with the relationship deterioration is signalled by Josefsson as well [4]. Pharmacological and orthopaedic treatment has a major impact on sexual satisfaction. However, drugs, in addition to body fluctuations, can affect the risk of impotence and lower libido and cause infertility [20, 21]. Orthopaedic treatment, e.g. hip arthroplasty, significantly improves mobility and reduces pain [22].

\section{Significance of physiotherapy in the process of treatment}

Properly arranged individual program of physical improvement contributes to satisfactory results of treatment and functional amelioration of patients. The goal of physiotherapy is to preserve, correct, and/or restore movement function. The multidimensional nature of lesions and the consequences of exacerbation of the disease are often a therapeutic problem. It is not always possible to change one segment of the movement system to another so as to eliminate overloading of the remaining structures. Quite often it is necessary to develop internal compensation mechanisms and to use orthopaedics and/or move supporting facilities. Physical therapy, therefore, through physiotherapy and kinesiotherapy along with orthopaedic supply, leans towards a synergistic effect with painkillers and antiinflammatory drugs. Physiotherapy prepares body tissues for further kinesiotherapeutic activities. It is used for reducing pain and inflammation and regulating muscle tone. Among the physiotherapeutic methods 
used, the following should be distinguished: local and whole-body cryotherapy and laser acupuncture as well as transcutaneous electrical nerve stimulation (TENS). Electrotherapy (stimulation, electroplating, interferential currents), magnetic fields, and laser therapy are also beneficial. Hydrotherapy treatments, including whirlpool, underwater, pearl, and aquavibron massage, also play a role in reducing the pain.

As mentioned above, kinesiotherapy is a basic element of the improvement of the locomotor system, which seeks to restore - if possible - the tension balance in the ligament-tendon-muscle system.

It affects the nutritional status of articular cartilage and increases the range of mobility of joints through various types of exercise (passive, isometric, active slow, self-assisted, unloaded, and unloaded with resistance), lifts, and manual therapy.

The intensity of the treatment must be adjusted to the patient's current state of health because exercises with too little intensity do not counteract muscle wasting and bone loss, while excessively expressive/dynamic exercises can aggravate cartilage or ligament injury and tendons, and lead to periosteal fractures. Prophylaxis is provided by orthopaedic supplies, which reduce pain by relieving the joints, enabling early start-up after surgery, and stabilises and corrects the destructive areas of the body [23].

\section{Physiotherapy and the sexuality of patients with rheumatic diseases}

Physiotherapy is included in the WHO-approved Polish model of rehabilitation, which is characterised by early action, continuity, accessibility, and comprehensiveness. Its goal is to restore the patient as quickly as possible and to the fullest extent of functional efficiency. It entails preventive actions - preventing the secondary consequences of illness and limited physical activity. It initiates activities that facilitate the process of regeneration, assisting and accelerating the compensation, as well as implementing adaptive behaviours that prepare the body for invalidity $[24,25]$. Physiotherapists - as recommended by EULAR - actively participate in an interdisciplinary therapeutic team supervised by a rheumatologist. According to their competences, they implement a program to improve the patient's health. Physical contact with the patient's body (touch) during therapy is conducive to a closer, more open relationship between the therapist and the patient. It also changes the way of communicating, which becomes friendlier.

Often the physiotherapist knows more about the problems of a patient than the physician performing basic pharmacological treatment. The communication between the patient and the doctor is different, mostly characterised by intellectual conversation [26]. Therefore, it can be assumed that systematic kinesiotherapy not only improves the physical performance of patients, but also positively influences the quality of sexual health. It is worth noting that women exercising regularly "are more likely to be sexually aroused" than men. This is due to increased testosterone secretion during training (mainly strength). This hormone affects a stronger sense of sexual desire. In addition, the exercises of pelvic floor muscles, the so-called Kegel exercises, may improve the orgasmic experience. Physical exercise also positively affects the sexual performance of men. It is an important factor reducing the occurrence of erectile dysfunction [27]. Regular exercise decreases fatigue, improves physical fitness, muscle strength and endurance, and coordinates movement and flexibility. Through exercise, patients can more easily maintain a good posture. Relief of resting heart rate, stabilisation of blood pressure, and better control of serum lipids level are examples of positive outcomes of exercise. However, in the case of pain-related complaints, specific to RA and AS, not every activity is recommended. The source of pain is arthritis, which causes increased tension in one structure due to changes in the surrounding, for example deficiency of the knee joint causes shortening of the rectus femoris muscle and the setting of the foot in the plantar fold. Dancing with knee flexion or walking/running do not bring relief but aggravate the pain and create new areas of pain due to improper pelvic and/or lower spine compensation.

The second, and thus far healthy, lower limb may also be overloaded, so the recommendations of a physiotherapist working together with rheumatologist focused on motion deficits are particularly important in improving the function of the skeletal-muscle system and programming kinesiotherapy. During remission, it is recommended that patients exercise three times a week for 30 minutes. In general, the "220 minus age" formula is used to calculate the training heart rate, and the number of heartbeats should be within the range of 130$170 /$ min. A quick walk in proper footwear, Nordic Walking, and/or swimming are examples of health efforts. There are only a few reports of methods of reducing pain before planned sexual contact. Some patients take medication, others undertake physical action - such as a warm shower $\left(37-38^{\circ} \mathrm{C}\right)$ relaxing muscles, or cold compresses to the most painful place. In the case of dryness symptoms, moisturising gels can be used around the intimate area. However, with inappropriate body position or excessive intensity of sexual contact, these measures may not be sufficient [28]. Therefore, the choice of position seems to be a necessary prerequisite for both part- 
ners to achieve satisfaction. The "teaspoon" position is safe for both partners. Partners lie on the less painful side, with bent knees and hip joints, as well as with face turned in one direction (the male partner is behind the woman's back). Such a position of bodies is suitable for many joints - it is painless for the spine and does not burden the hands, allowing for great mobility. In the case of hip or knee pain, or post-prosthetic arthroplasty, it is necessary to put the body on the unoperated side, with a rolled up blanket or a thick cushion between the legs. It should be also ensured that the mattress has adequate hardness because if it is too soft, it may cause sprains of the prosthesis during frictional movements.

"The rider" position is especially beneficial for men with multiple joint and spine complaints. A passive position on the back, sometimes with pads under the knee and the head, on a mattress of adequate hardness guarantees safe and painless sexual intercourse. This position is a good solution for partners who value eye contact. When the woman is disabled the affected limbs and spine may be a significant limitation in this position. The pain in the upper segments of the spine and joints of the upper limbs (shoulder, elbows, arms) will not constitute discomfort. The position of "the rider" in the chair is a modification of the above-mentioned position. This position allows for close physical contact between the partners. It is recommended for female partners with lower limb and spine deficits. The absolute contraindications in this case are changes in the lower limbs, while the relative contraindications are pain in the neck and upper limbs. For patients suffering from hip and spine pain, "from behind" is the preferred position. Both partners are on their knees with forearms supported at the appropriate height (bed, chair). It makes it possible to find such position of the body in which patients do not perform full range of movements, and thus do not induce pain within the occupied tissue. This position should be eliminated in the case of knee arthritis, surgical procedures (endoprosthetic surgery), and severe inflammation in the wrists, shoulders, and back [29].

\section{Conclusions}

The literature confirms that sexuality correlates with quality of life. It is an innate characteristic of every human being and an important element of our existence. Due to the positive influence on both general health and other spheres of life, partner relationships, well-being, and self-esteem, sexuality plays a special role in the life of persons with rheumatic diseases [30]. Chronic illness and disability create many barriers and difficulties in the sexual sphere. Rheumatic disease alone does not affect sexual satisfaction of patients, but the symptoms of the disease significantly affect the decreased level of sexuality and cause difficulties in partnering. Pain, fatigue, decreased physical activity, and depression are the most commons symptoms that impede sexual life.

The sexuality of patients is also affected by the complaints associated with pharmacotherapy and surgical treatment. In order to improve sexual health, the main symptoms affecting sexuality should be reduced. The most important physiotherapeutic activities include the reduction of pain and the improvement of physical fitness of patients through physical activity. Patients should be educated on issues related to the selection of appropriate positions and sexual behaviours. All of the symptoms mentioned above are responsible for limiting family size, limiting sexual ability and satisfaction, affecting the disease, and acting on drugs to worsen the gonadal. Among the many directions of therapeutic activities there should also be a place for sexual counselling among "rheumatic" patients.

The authors declare no conflict of interest.

\section{References}

1. Nomejko A, Dolińska-Zygmunt G, Zdrojewicz Z. Poczucie jakości życia a satysfakcja z życia seksualnego - badania własne. Seksuologia Polska 2012; 10: 54-60.

2. Lew-Starowicz Z. Psychospołeczne podstawy seksualności. In: Podstawy seksuologii. Lew-Starowicz Z, Skrzypulec V (eds.). Wyd. Lekarskie PZWL, Warszawa 2010.

3. Ostrowska A.Zdrowie-ciało-seks. In: Izdebski Z, Ostrowska A. Seks po polsku. Muza SA, Warszawa 2003.

4. Areskoug-Josefsson K. Sexual health in patients with rheumatoid arthritis: experiences, needs and communication with health care professionals. Musculoskelet Care 2012; 10: 76-89.

5. Alcala JM, Douat D, Pinheiro DL, et al. Radiographic changes of cervical spine in rheumatoid arthritis. Rev Bras Reumatol 2013; 53: 388-393.

6. Głuszko P. Najczęściej występujące choroby reumatyczne. In: Fizjoterapia w reumatologii. Księżopolska-Orłowska K (ed.). Wyd. Lekarskie PZWL, Warszawa 2013.

7. Księżopolska-Orłowska K, Żuk B. Diagnostyka stawów w chorobach reumatoidalnych. In: Anatomia układu ruchu z elementami diagnostyki reumatologicznej. Wisłowska M, Księżopolska-Orłowska K, Żuk B. Wyd. Lekarskie PZWL, Warszawa 2013.

8. Stanisławska-Biernat E. Zesztywniające zapalenie stawów kręgosłupa. In: Fizjoterapia w reumatologii. Księżopolska-Orłowska K (ed.). Wyd. Lekarskie PZWL, Warszawa 2013.

9. Filipowicz-Sosnowska A. Reumatoidalne zapalenie stawów. In: Reumatologia kliniczna. Tom II. Zimmermann-Górska I (ed). Wyd. Lekarskie PZWL, Warszawa 2009.

10. Kucharz E. Reumatoseksuologia: wprowadzenie do problematyki interdyscyplinarnej. Reumatologia 2010; 48: 155-158.

11. Van Berlo WTM, van de Wiel HBM, Taal E, et al. Sexual functioning of people with rheumatoid arthritis: a multicenter study. Clin Rheumatol 2007; 26: 30-38. 
12. Kobelt G, Texier-Richard B, Mimoun S, et al. Rheumatoid arthritis and sexuality: a patient survey in France. Musculoskeletal Dis 2012; 13: 170 .

13. World Health Organization defining sexual health. Report of a technical consultation on sexual health. 28-31 January 2002 Geneva. Sexual health document series. Geneva 2006.

14. Saadat SH, Ramezani A, Ahmadi K. Sexual Self-Concept and General Health in Rheumatoid Arthritis Patients. Iran Red Crescent Med J 2015; 17: e19005.

15. Miedany YE, Gaafary ME, Aroussy NE, et al. Sexual dysfunction in rheumatoid arthritis patients: arthritis and beyond. Clin Rheumatol 2012; 31: 601-606.

16. Rosen R, Brown C, Heiman J, Leiblum S. The Female Sexual Function Index (FSFI): a multidimensional self - report instrument for the assessment of female sexual function. J Sex Marital Ther 2000; 26: 191-208.

17. Abdel-Nasser AM, Ali El. Determinants of sexual disability and dissatisfaction in female patients with rheumatoid arthritis. Clin Rheumatol 2006; 25: 822-830.

18. Akkurt HE, Yilmaz H, Yilmaz S, et al. Evaluation of Sexual Dysfunction in Females With Ankylosing Spondylitis. Arch Rheumatol 2012; 31: 41-47.

19. Hill J, Bird H, Thorpe R. Effects of rheumatoid arthritis on sexual activity and relationships. Rheumatology 2003; 42: 280-286.

20. Moskalewicz B, Grygielska J, Mańczak M. Związki intymne chorych reumatycznych w opinii profesjonalistów zdrowia, chorych i ich partnerów. Reumatologia 2010; 48: 330-336.
21. Stern SH, Fuchs MD, Ganz SB, et al. Sexual function after total hip arthroplasty. Clin Orthop Related Res 1991; 269: 228-235.

22. Księżpolska-Orłowska K. Zasady fizjoterapii w chorobach reumatycznych. In: Fizjoterapia w reumatologii. Księżpolska-Orłowska K (ed.). Wyd. Lekarskie PZWL, Warszawa 2013.

23. Lubecki M. Polski model rehabilitacji medycznej zaakceptowany i zalecany przez WHO. Hygeia Public Heath 2011; 46: 506-515.

24. Kiwerski J. Podstawy tworzenia programu rehabilitacji. In: Kiwerski J. Fizjoterapia ogólna. Wyd. Lekarskie PZWL, Warszawa 2012.

25. Josefsson KA, Gard G. Women's experiences of sexual health when living with rheumatoid arthritis - an explorative qualitative study. BMC Musculoskelet Dis 2010; 11: 240.

26. Moskalewicz B, Grygielska J. Intymne związki i choroby reumatyczne. In: Ostrowska A. O seksualności osób niepełnosprawnych. Instytut Rozwoju Służb Społecznych, Warszawa 2007: 131-140.

27. Skorupska S, Szeligowska J, Mamcarz A. Marsza dla zdrowia seksualnego. Przegląd Menopauzalny 2011; 10: 454-456.

28. Cichocki T. Rola fizjoterapeuty $w$ rozwiązywaniu problemów związanych z seksualnością. In: Fizjoterapia w reumatologii. Księżpolska-Orłowska K (ed.). Wyd. Lekarskie PZWL, Warszawa 2013.

29. Cichocki T. Partnerstwo i seks osób chorych na choroby reumatyczne. Available at: http://idn.org.pl/reuma/blizej.pdf.

30. Tristano A. The impact of rheumatic diseases on sexual function. Rheum Intern 2009; 29: 853-860. 